\title{
Iconoclastia e milagre: a Passio Imaginis na Península Ibérica (séculos XIII-XVII)
}

\section{Debora Gomes Pereira Amaral'}

Resumo: Neste artigo analisaremos, por meio de relatos sobre ataques a crucifixos milagrosos (séculos XIII-XVII) e de processos de Fé da Inquisição espanhola, como a lenda da Passio Imaginis de Beirute repercutiu na Península Ibérica e suas possíveis influências nas acusações de ataques iconoclastas à imagem considerada a mais importante para a fé cristã, o Cristo-Imagem.

Palavras-chave: Passio Imaginis. Iconoclastia. Crucifixo Milagroso. Inquisição Ibérica.

\section{Iconoclasm and miracle: the Passio Imaginis in the Iberian Peninsula (13th- -17 th centuries)}

\begin{abstract}
In this article we will analyze, by reports of attacks on miraculous crucifixes (13th-17th centuries) and the processes of Faith of the Spanish Inquisition, how the legend of the Passio Imaginis of Beirut reflected in the Iberian Peninsula, and its potential influences on the accusations of iconoclastic attacks to the image considered as the most important for the Christian faith, the Christ-Image.
\end{abstract}

Keywords: Passio Imaginis. Iconoclasm. Miraculous Crucifix. Iberian Inquisition.

I Doutoranda em História pelo PPGHS-USP escrevendo a tese "Virtus Sancta: Iconoclastia e Imagens Milagrosas na Península Ibérica Tardo-Medieval". Mestra em História pelo PPGHS-USP com a dissertação "A Iconoclastia nas Pinturas da Capela do Antigo Convento do Cristo da Paciência de Madri (século XVII)". Bacharel em História-USP. Pesquisadora do LATHIMMUSP. Discente da Universidade de São Paulo, PPGHS-USP - Av. Professor Lineu Prestes, 338, Cidade Universitária, Butantã - 05508-000 - São Paulo, SP. E-mail: debora.amaral@usp.br. ORCID: https://orcid.org/0000-0001-8779-2511. Lattes iD: http://lattes.cnpq.br/6619750952805522. São Paulo, SP. 
Prius enim propter nos et propter salutem nostram, cum esses sine carne, incarnatus ex Virgene Marie, crucifixus es in illa carne [...] Nunc vero iterum in imagine crucifixus es, Domini, in redargutionem impiorum et omnium incredulorum, atque stabilitatem eorum qui veraciter in te credunt... ${ }^{1}$

No segundo Concílio de Nicéia (787), durante a leitura pelo bispo Pedro de Nicomédia do Sermo sanctae memoriae Patris nostri Athanassi de imagini Domini nostre lesu Christi veri Dei nostri, facto miraculo in civitati Beryto, atribuído a Pseudo-Atanásio, todos os bispos partidários da iconodulia teriam caído em lágrimas ${ }^{2}$. O sermão, que descreve um crucifixo que teria vertido água e sangue ${ }^{3}$ em resposta a um ataque iconoclasta, faria de tal relato uma "prova" dos argumentos ${ }^{4}$ apresentados contra as teses iconoclastas e em favor da manutenção do culto às imagens cristãs. No decorrer dos séculos seguintes a narrativa foi transladada para o Ocidente cristão, chegando à Península Ibérica, onde contribuiu para a formação de outras lendas em que crucifixos teriam reagido milagrosamente após serem agredidos, como no caso da lenda e do culto ao Santíssimo Crucifixo Salvador de Valência (após o século XIII), ou de sua reinterpretação/rememoração na lenda do Santíssimo Cristo da Paciência de Madri (século XVII), que foi fruto de uma denúncia feita ao Tribunal do Santo Ofício. Neste artigo pretendemos analisar, por meio de narrativas e de Processos de Fé da Inquisição espanhola, como a lenda da Passio Imaginis repercutiu na Península Ibérica e quais suas possíveis influências nas acusações de ataques iconoclastas à imagem mais importante para a fé cristã, o Cristo na cruz, tendo em vista que, no final do medievo e início da modernidade, aquela região estava imersa em controvérsias religiosas, nas quais o culto às imagens ( $e$, por consequência o desrespeito a elas) foi tema basilar, sobretudo no que diz respeito às relações entre as comunidades cristã, judaica e muçulmana.

1 "Primeiro, por nós e para nossa salvação, se fez carne pela Virgem Maria, e foi crucificado [...]. Agora em imagem foi crucificado novamente para desprezo dos ímpios e dos incrédulos e para fortalecer a todos que acreditam em ti" (nossa tradução). Sermo sanctae memoriae Patris nostri Athanassi de imagini Domini nostre lesu Christi veri Dei nostri, facto miraculo in civitati Beryto. In: Atti del concilio ecumenico di Nicea (787), na tradução de Anastacio Bibliotecário (873); In: Mansi, 1759-1798, p. 27

2 Mansi, 1759-1798, p. 31.

3 Os líquidos tornaram-se relíquias milagrosas, capazes de curar enfermos, detalharemos a lenda mais à frente.

4 Argumentos estes baseados na teoria do transitus de João Damasceno, uma vez que o crucifixo ao reagir milagrosamente demonstraria que ele participava da divindade de seu protótipo. Garcia Aviles, 2011, p. 25-35. 
Como é muito sabido, a presença de judeus na Península Ibérica antecede a conversão daquela província do Império Romano ao cristianismo, que por sua vez antecede à chegada dos muçulmanos, no início do século VIII. Após a Reconquista cristã dos territórios ibéricos ${ }^{5}$, a permanência de comunidades de judeus e muçulmanos não deixou de ser causa de desavenças com a sociedade crista hegemônica, e a utilização de imagens de culto participou do acirramento dessas desavenças. As conversões em massa ao cristianismo, a pressão sobre os conversos e as constantes ameaças da Inquisição acabaram revivendo antigas polêmicas e novas incertezas relacionadas às imagens devocionais, principalmente no que diz respeito à sua presença nos lares ${ }^{6}$. As frequentes acusações de profanação ritual levaram alguns conversos a recear possuir imagens e crucifixos, como é o caso do livreiro Luiz Garcia ou Abraham García, que temia ter crucifixos em sua casa receando ser acusado de simular a Paixão de Cristo e de atacar um crucifixo ${ }^{7}$.

Foi em meio a este contexto de disputas religiosas e territoriais que se conformou a lenda do Santíssimo Cristo do Salvador, que narra que em 9 de novembro ${ }^{8}$ de 1250 um crucifixo foi encontrado flutuando no rio Turia, sendo então levado para a igreja de San Jordi (São Jorge), uma antiga mesquita que fora convertida em igreja após a tomada do reino de Valência em 1238 pelo rei de Aragão, Jaime $~ I^{9}$. O bispo de Valência, considerando a imagem um prodígio divino, resolveu que o melhor lugar para ela seria a catedral; porém, no dia seguinte milagrosamente a imagem teria retornado para a igreja de São Jorge. Entendendo ser este o desejo do Cristo-imagem, o eclesiástico decidiu que a imagem seria cultuada naquele local, e com o decorrer dos anos a igreja acabou por ser designada igreja do Santísimo Cristo del Salvador. Até hoje a imagem é ainda ali cultuada. Essa lenda se configura como uma decorrência da Passio Imaginis do Cristo de Beirute, aquela relatada no

5 Sobre este tema ver, entre outros: García Fitz, 2009, p. 142-215; Rucquoi, 1995; Bishko, 1975, p. 396-456.

6 Espeso Pereda, 2007, Posição 340-5673.

7 Apud: Espeso Pereda, 2007, Posição 421-5673.

8 Em algumas legendas esta seria a mesma data em que o milagre de Beirute teria ocorrido. Também em algumas localidades é em 9 de novembro que se comemora a Exaltação da Cruz e a Passio Imaginis Domini. Arciniega García, 2012, p. 71; Sansterre, 1999, p. 118.

9 Ferrer Navarro, 1999. 
Concílio de Niceia $\mathrm{II}^{10}$, pois o Santíssimo Cristo do Salvador valenciano foi reconhecido como sendo o mesmo venerado em Beirute, que teria permanecido nesta cidade até 1229 , quando, sob a invasão muçulmana, teria sido lançada por estes ao mar. A imagem teria então, milagrosamente, cruzado o Mediterrâneo até aportar em terras valencianas ${ }^{11}$.

A outra lenda analisada neste artigo é a do Cristo da Paciência ${ }^{12}$, que conta que três famílias de cristãos-novos portugueses teriam sido acusadas pela Inquisição espanhola do ataque a um crucifixo que milagrosamente teria reagido, sendo assim condenadas no primeiro grande Auto de Fé em Madri (1632). O suposto ataque iconoclasta havia sido delatado em 1630 e os acusados foram conduzidos ao cárcere do Santo Oficio de Toledo para interrogatório. Porém, o que chamou mais a atenção dos inquisidores foi o depoimento do filho mais novo de um dos acusados, de apenas seis anos ${ }^{13}$. A criança foi interrogada por três vezes, sempre confirmando a profanação, embora no último interrogatório tivesse acrescentado um fato que acirraria os ânimos dos Inquisidores: ao ser açoitada, a imagem do Cristo crucificado teria questionado oralmente seus algozes, além de ter sangrado e ter resistido ao fogo. Em 1651, após o Auto de Fé e com o apoio da Coroa, foi erigido no local onde as famílias moravam um templo expiatório adornado com pinturas narrando o desacato e o milagre. Nesse local se desenvolveria mais tarde o culto ao Cristo de la Paciencia, celebrado por inúmeros sermões em festas de desagravo, e que sobreviveria até a demolição da Igreja no início do século XIX. Notemos que este relato milagroso é quase idêntico ao milagre do Cristo de Beirute, com a diferença de que os cristão-novos, recém convertidos da fé judaica, não teriam se arrependido ${ }^{14}$.

Devemos lembrar que tanto para judeus como para muçulmanos o culto

10 Varazze, 2003, p.770-771; Sansterre, 1999, p. 113-130.

11 Ballester, 1672.

12 Em nossa dissertação de mestrado analisamos esta lenda. Amaral, 2016.

13 AHN Inq. Leg. 140 Caixa 2 Exp. 4h, Proceso de Miguel Rodriguez. As declarações de Andresilho, menino que teria acusado os pais, estão anexadas ao processo de seu pai, Miguel Rodriguez.

14 Destacamos que existe uma importante diferença com relação ao suposto milagre em Beirute, eram judeus que praticaram o ato iconoclasta, já em Madri a conversão teria ocorrido antes da profanação, o que tornaria tal ação muito mais dolosa. 
às imagens religiosas é compreendido em geral como um ato idólatra ${ }^{15}$, de modo que essas religiões acabaram por ser vinculadas a atos iconoclastas. Também é importante pontuar que as conversões forçadas não resolveram as tensões religiosas, longe disso, tendo aberto espaço para a atuação da Inquisição. Assim, quando investigamos a documentação do Tribunal do Santo Oficio encontramos diversos processos em que cristãos-novos, tanto marranos (convertidos do judaísmo) como mouriscos (convertidos do islamismo), são acusados de praticarem delitos contra as imagens sagradas ${ }^{16}$.

\section{Passio Imaginis}

A lenda que está na origem daquelas citadas acima, a da Passio Imaginis, ou do milagre do Cristo de Beirute, narra que um cristão, dono do objeto religioso, era obrigado a mantê-lo escondido por viver em uma vizinhança judia em Beirute e temer sua ira. Porém, quando mudou de domicílio, teria esquecido no local a imagem do Cristo Crucificado. A casa então fora alugada por um judeu que não notou a presença do crucifixo em seus aposentos, até que em um jantar um de seus convidados, ao ver a imagem, disse-lhe ser impróprio para um membro da fé hebraica possuir tal objeto. $O$ anfitrião justificou-se dizendo que não havia percebido sua presença, mas mesmo assim o convidado o denunciou perante os anciãos do Sinédrio. Diante de tal denúncia, os membros da comunidade hebraica teriam decido invadir a casa do suspeito de apostasia para confirmar as acusações. Quando viram a imagem, resolveram sobre ela repetir os tormentos que seus ancestrais teriam infligido ao Cristo em Jerusalém, espancando-a com um bastão, dando-lhe vinagre e fel para beber, e perfurando-a com uma lança. No entanto, quando a lança perfurou a efígie, dela começou a fluir sangue e água, para estupefação dos anciões. Ainda não convencidos, os judeus recolheram o líquido precioso em um recipiente, e com a intenção de confirmar a veracidade da virtude milagrosa da imagem, convocaram um paralítico e um cego que, ao entrarem em contato com tais líquidos, foram curados. Desta feita, os judeus de Beirute anunciaram o milagre ao bispo da cidade, pediram para ser batizados (no que foram atendidos) e a sinagoga foi transformada em igreja, consagrada ao Salvador.

15 Besançon, 1997, p. 121-135.

16 Não estamos aqui tomando como fato verídico todas essas acusações, mas antes apontando uma ideia que circulava entre as autoridades católicas, a de que os cristãos-novos não teriam abraçado a fé católica sinceramente, o que seria denotado por supostos atos de ataques aos objetos visuais sagrados. 
O bispo de Beirute, que em algumas fontes é denominado como Adeodato ${ }^{17}$, recolheu então em pequenas ampolas o sangue e a água resultante do milagre e as enviou para outras localidades do mundo cristão (África, Ásia e Europa) ${ }^{18}$.

O relato bizantino do milagre que supostamente ocorrera no século IV teria sido lido, como já dissemos, para os bispos conciliares durante uma das seções do Concílio de Nicéia $1{ }^{19}$ comovendo a plateia partidária da iconodulia ${ }^{20}$. Apesar de já ser então conhecido pela a Igreja de Roma desde 787, com a primeira versão latina das Atas do Segundo Concílio Ecumênico de Nicéia ${ }^{21}$, cheia de erros e inconsistências, e com as anotações apresentadas nos Libri carolini ${ }^{22}$, foi através as traduções do grego para o latim dos Atos de Nicéia II feitas em 872 pelo bibliotecário de Roma, Anastácio (810-873), que realmente a lenda da Passio Imaginis tornou-se conhecida no Ocidente latino. ${ }^{23} \mathrm{~A}$ lenda funcionou como um dos argumentos contra as teses iconoclastas (muitas vezes acusadas pelos eclesiásticos iconófilos de serem uma espécie de renascimento de antigas crenças judaicas) ${ }^{24}$ no Concílio de Nicéia II, pois colocou em perfeita evidência o valor do ícone como um sinal material capaz de tornar a verdade divina acessível e associada à imagem sagrada ${ }^{25}$. Para entendermos como esta narrativa pode ser empregada como argumento em defesa do culto às imagens religiosas, devemos compreender que os iconófilos bizantinos desenvolveram uma teoria da imagem segundo o grau de afinidade com seu respectivo protótipo, cujo ápice é o Cristo, a imagem consubstancial de Deus ${ }^{26}$.

17 Como no manuscrito da Biblioteca Apostólica do Vaticano: Vat. Lat. 641, fl. 135v.

18 Mansi, 1759-1798, pp. 26-31 e 580-586; Sansterre, 1999, p.113-130; Bacci, 2002, p. 7-86; Schmitt, 2007, p. 201-218; Arciniega García, 2012 p. 71-94; Espí Forcín, 2014; Aron-Beller, 2017.

19 Sansterre, 1999, p. 118; Bacci, 2002, p. 9.

20 Schmitt, 2007, p. 226.

21 Bacci, 2002, p. 17.

22 Nos Libri carolini aparecem críticas àqueles que utilizaram o pseudo-Atanásio para defender as imagens. Schmitt, 2007, p. 226.

23 Bacci, p. 17.

24 Garcia Aviles, 2011, p. 31.

25 Bacci, 2002, p. 10.

26 A encarnação é [...] uma etapa decisiva na história da relação de imagem. O Filho é, com efeito, a imago perfeita do Pai divino, e os teólogos sublinham que essa relação 
O sucesso cultual da imagem de Beirute e de seu sangue milagroso foi, em primeiro lugar, uma consequência do enraizamento de antigas lendas na cultura eclesiástica bizantina ${ }^{27}$ e continuou a desempenhar um papel importante na formulação oficial da doutrina das imagens, cuja fama chegou até o Ocidente latino. A partir dos séculos X-XI, o sermão do Pseudo-Atanásio foi incluído nas coleções homiléticas com frequência cada vez maior, como um texto destinado à leitura do chamado Domingo dos Ortodoxos, que comemorava a restituição das imagens em 843 , inaugurando o período quaresma ${ }^{28}$. No século $X$, a lenda foi incluída no calendário litúrgico romano, sendo celebrada sua festa em 9 de novembro.

Por volta do século $\mathrm{XI}$, a narrativa sofreu um acréscimo em um manuscrito (conservado atualmente no Vaticano) que enriqueceu o valor devocional do crucifixo de Beirute ${ }^{29}$. O bispo Adeodato teria procurado o cristão dono desse objeto sagrado e ao questioná-lo sobre sua origem, foi informado de que a imagem teria sido feita pelo próprio Nicodemos, que é citado no Evangelho de João: um judeu que reconheceu a divindade de Cristo $(3: 1-20)^{30}$, defendeu-o diante dos chefes sacerdotes (7:50-52) ${ }^{31}$ e, com José de Arimateia (19: 39-40) $)^{32}$, quando Jesus morreu, sepultou seu corpo. Nicodemos teria então confiado o crucifixo ao Rabino Gamaliel, que na sequência o teria deixado a

supera em dignidade aquela que existe entre o Criador e o homem [...]. Permanece o fato de que a encarnação de Cristo relativiza a dessemelhança aberta com a Queda e permite aos homens reconquistar a imagem divina perdida. Baschet, 2006, p. 510; Garcia Aviles, 2011, p. 26.

27 Bacci, 2002, p. 10-23.

28 Bacci, 2002, p. 14.

29 Vat. Lat. 641, fl. 134-136; impresso: Froz, 1891-1901, 4229b.

30 Havia, entre os fariseus, um homem chamado Nicodemos, um notável entre os judeus. À noite ele veio encontrar Jesus e lhe disse: Rabi, sabemos que vens da parte de Deus como mestre, pois ninguém pode fazer os sinais que fazes [milagres], se deus não estiver com ele". João (3:1-20)

31 Nicodemos, um deles, o que anteriormente viera a Jesus, disse-lhes: "Acaso nossa lei condena alguém sem primeiro ouvi-lo e saber o que fez? "Responderam-lhe: És galileu? Estuda e verás que da Galileia não surge profeta". João (7:50-52)

32 Depois, José de Arimatéia, que era discípulo de Jesus, mas secretamente, por meio dos judeus, pediu a Pilatos secretamente que Ihe permitisse retirar o corpo de Jesus. Pilatos permitiu. Vieram, então, e retiram seu corpo. Nicodemos, aquele que anteriormente procurou Jesus à noite, também veio, trazendo cerca de cem libras de uma mistura de mirra e aloés. Eles tomaram então o corpo de Jesus e o envolveram em faixas de linho com os aromas, como os judeus costumam sepultar. (João 19: 39-40) 
Zaqueu e assim por diante, até a destruição do Templo de Jerusalém no ano de 70, quando ele teria vindo com os ancestrais do cristão dono do crucifixo da Palestina para Beirute ${ }^{33}$. Nesta nova versão foi reconhecida a origem excepcional da efígie, e só após esta "certificação" é que o bispo teria batizado os profanadores e convertido a sinagoga em igreja cristã, inaugurando, assim, a tradição de dedicação de igrejas ao Salvador. Estabeleceu-se com isso a festa do Salvador em 9 de novembro, precisando-se que sua celebração deveria ser tão exaltada quanto as celebrações da Páscoa e do Natal. ${ }^{34}$

A atribuição da origem do objeto milagroso a Nicodemos reforçou a importância do milagre de Beirute, assim como reforçou a ideia de repetição da Paixão: foi construída deste modo, mais explicitamente, uma equivalência entre a imagem perfurada e o personagem nele figurado. A origem maravilhosa do crucifixo foi amplificada pelo contato, pois Nicodemos, como já dissemos, teria tido contato direto com o corpo de Cristo.

\section{Do Bizâncio para a Península Ibéria}

Como já citamos, a lenda da Passio Imaginis tornou-se conhecida na Europa Ocidental pela tradução de Anastácio, bibliotecário de Roma, dos Atos de Nicéia II após $872^{35}$ e não demorou muito para que ela começace a ser descrita em textos latinos. No início do século XII, Sigeberto de Gembloux (1030-1112) descreve em suas Crônicas o milagre de Beirute, datando o suposto milagre no ano de 765, quando Constantino IV, defensor do culto às imagens religiosas, era imperador. Foi também nesta mesma época que Helinando de Froidmont (1150-1229) inseriu os opróbios e o milagre do crucifixo de Beirute em suas Crônicas. No Speculum historiale, Vicente de Beauvais (1190-1264) também incluiu o relato da Passio Imaginis, assim como fez Alberto de Lieja (1166-1192) em sua obra Alphabetum narratio-

33 Bacci, 2002, p.17-19; Arciniega García, 2012, p. 71-94.

34 Bacci, 2002, p. 17-19. Ver também: Arciniega García, 2012, p. 71-94, 2012; Espí Forcín, , 2014; Aron-Beller, 2017.

35 Apesar da primeira versão latina ter sido produzida em 787, estava cheia de erros e inconsistências, foi somente no século IX, com a tradução de Anastácio, que ela passou a ser difundida. Bacci, 1999, p. 17. 
num $^{36}$ e Jacopo de Varazze (1228-1298) em sua Legenda Aurea ${ }^{37}$. Estes são apenas alguns exemplos de textos elaborados na Europa latina que narraram a lenda do milagre de Beirute.

No caso da Península Ibérica, a difusão e o uso litúrgico da lenda da Passio Imaginis se afirmou precocemente na região da Catalunha. A propagação da celebração andou pari passu com a proliferação de relíquias como as ampolas de sangue da imagem. Na região da atual Espanha, a abadia de Sant Pere de Rodes em Girona, na Catalunha, e a "Arca Santa", o grande relicário que contém inúmeras relíquias da Catedral de Oviedo, possuíam ampolas com líquido milagroso desde pelo menos os séculos $\mathrm{X}$ e XI. ${ }^{38}$

Devemos lembrar que a consagração como relíquia das ampolas com o sangue do crucifixo de Beirute serve de certa forma como substituto ao sangue do próprio Cristo, posto que alguns teólogos medievais já haviam assumido a inexistência de relíquias corporais de Cristo, uma vez que ele ressuscitara. Como podemos ler nos quatro evangelhos ${ }^{39}$, o túmulo estava vazio, apenas com faixas e panos mortuários; assim, ao ressuscitar, Cristo não teria deixado vestígios físicos na terra. Ao ler o sermão no Concílio de Nicéia II, o bispo Pedro de Nicomédia insistira que o sangue que vazou da imagem em Beirute era de fato a única verdadeira relíquia do sangue de Cristo no mundo e precisava ser entendido como tal ${ }^{40}$, reforçando a negação do status de relíquia a qualquer outro sangue que fosse atribuído ao Cristo quando de sua Crucificação ${ }^{41}$.

Mais adiante, no século XII, no Ocidente latino, Tomás de Aquino, na Questão 54 do Tomo III da Suma Teológica, ao discutir se o corpo de Cristo ressurgiu inteiro ${ }^{42}$ retoma o tema tratado por Pedro de Nicomédia. Ele termina o artigo 2 desta questão concluindo que o sangue que as igrejas têm guardado em seus relicários não seria o sangue do Cristo humano, mas sim do Cristo-imagem, que milagrosamente sangra quando atacada, como podemos

36 Bacci, 1998, p, 10; Aron-Beller, 2017, p. 57.

37 Varazze, 2003, p. 770.

38 Bacci, 2014, p. 52.

39 Mateus 28:1-8; Marcos 16:1-7; Lucas 24:1-11 e João 20:1-9.

40 Mansi, 1759-1798, p. 585.

41 Sansterre, 1999, p. 120; Bacci, 1998, p. 8-9.

42 Santerre, 1999, p. 120. 
ler no excerto a seguir:

Todo o sangue corrido do corpo de Cristo, pertencendo realmente à natureza humana, ressurgiu com o seu corpo. E o mesmo devemos dizer de todas as partículas realmente pertencentes à natureza humana em sua integridade. Quanto ao sangue conservado por certas igrejas como relíquias, esse não correu do lado de Cristo; mas é considerado como tendo jorrado milagrosamente de alguma imagem sua, objeto de qualquer violência ${ }^{43}$.

Ou seja, o sangue das ampolas espalhadas pelas Igrejas durante o período medieval seria considerado então fruto de um ataque iconoclasta a crucifixos, uma relíquia de uma efígie (objeto inanimado) e não da divindade encarnada.

Segundo Michele Bacci, a grande relevância simbólica atribuída ao culto ao sangue da imagem de Cristo é frequentemente revelada pelos calendários litúrgicos do século $\mathrm{X}$ até o XV, nos quais a expressão Passio Imaginis muitas vezes foi substituída por Salvator. ${ }^{44} \mathrm{Em}$ outras palavras, a celebração do milagre do crucifixo sangrante de Beirute passou a ser denominada, em algumas localidades, como a festa do Salvador. O costume de dedicar igrejas e altares à imagem do Salvador parece ter sido amplamente difundido em Aragão: como o altar em homenagem à Passió de la imatge de Crist erguido na Catedral de Vic durante o século XIII e a capela da Pasión de la Imagen na Sé de Valência, do final do século XIII. Além disso, o milagre de Beirute constituiu uma das principais festas nas igrejas dedicadas ao Salvador, o que demonstra que neste período a celebração da Paixão da Imagem de Cristo fazia-se presente em várias regiões da Península Ibérica. Ademais, no contexto da Reconquista muitas mesquitas foram convertidas em igrejas dedicadas ao Salvador, como teria acontecido em Beirute, quando a sinagoga fora convertida em igreja cristã após o milagre da Passio Imaginis.

Para além das celebrações, algumas obras teológicas, em geral de cunho antijudaico, trataram da lenda da Passio Imaginis, a exemplo da Fortalitium Fidei $^{45}$ (1458), do franciscano Alonso de Espina (s/d-1496). Para o histo-

43 Aquino, versão online: http://permanencia.org.br/drupal/node/3512. Acesso em $24 / 04 / 2019$

44 Bacci, 1998, p.10.

45 Fortalitium Fidei escrito em latim e apesar de muitos historiadores, classificarem a obra como antissemita, segundo Félix-Tomás López Gurpegui, que traduziu o livro III para 
riador Espeso Pereda, o franciscano faz no Livro III da sua obra a primeira elaboração de uma teoria sacramental da imagem religiosa na região da Península Ibérica. Segundo Pereda, Espina conseguiu tal elaboração ponderando dois polos, a teologia e as práticas devocionais, vinculando, à sua maneira, as colocações de João Damasceno e de Tomás de Aquino com as legendas medievais de imagens milagrosas ${ }^{46}$, como a do milagre do Cristo de Beirute ${ }^{47}$. Outra obra que foi muito importante no contexto das relações entre conversos e cristãos e do culto ao crucifixo foi a do dominicano e inquisidor de Valência Jaime Juan de Bleda (1550-1622) ${ }^{48}$, Cuatrocientos milagros, y muchas alabanças de la santa Cruz, impressa em 1600. Entre os 400 milagres compilados pelo inquisidor estão alguns em que o crucifixo se manifesta milagrosamente após ser atacado, como o milagre $106^{49}$, Como mano mucho sangre de la ymagens de um crucifixo que irio um judio con una lança, que narra a lenda do crucifixo de Beirute.

A lenda da Passio Imaginis não circulou somente por textos na Europa latina, ela foi também representada visualmente. Já em meados do século XII encontramos uma figuração da Passio Imaginis em uma inicial figurante ${ }^{50}$ $S$ de um Passional (1160), obra que narra a vida de mártires da Abadia de Zwiefalten e está conservado na biblioteca Württembergische de Sttutgart $^{51}$. No caso da região peninsular, nem todas as imagens ainda existem, mas temos conhecimento de algumas por meio de documentação contemporânea, como a encomenda de 1404 ao pintor Lluís Borrassà, na qual se pede que pintasse a predela do retábulo da vida de Jesus Cristo para a

o espanhol, o objetivo de Espina seria compor uma persuasão política e religiosa não só contra judeus, mas também contra os muçulmanos na Espanha, além de não esconder seu desejo de que uma Inquisição que pudesse atuar com força na Espanha. Gurpegui, 2014.

46 Espeso Pereda, 2007, Posição 1056/9-5673.

47 Espina, Edição Kindle, Posição 5377- 6683.

48 Jaime Juan de Bleda além de ocupar cargos importantes na hierarquia da Igreja Católica Espanhola, atuou politicamente na corte de Felipe III e em Roma, a favor da expulsão dos mouriscos na Espanha. Sáez, 2013, p. 103-118.

49 Bleda, 1600, p. 301-304.

50 Usando aqui o conceito de Maria Cristina Pereira para classificar as iniciais que "tomam parte, mais ou menos ativamente, da imagem (ou das imagens) que abrigam". Pereira, 2019, p. 42

51 Espí Forcín, 2008, p. 198 e 306; Arciniega García, 2012, p. 74. 
Figura 1

Retábulo, séc.

$X V$, igreja de São Miguel em Felanitx de Mallorca.

Fonte: Wikimedia.

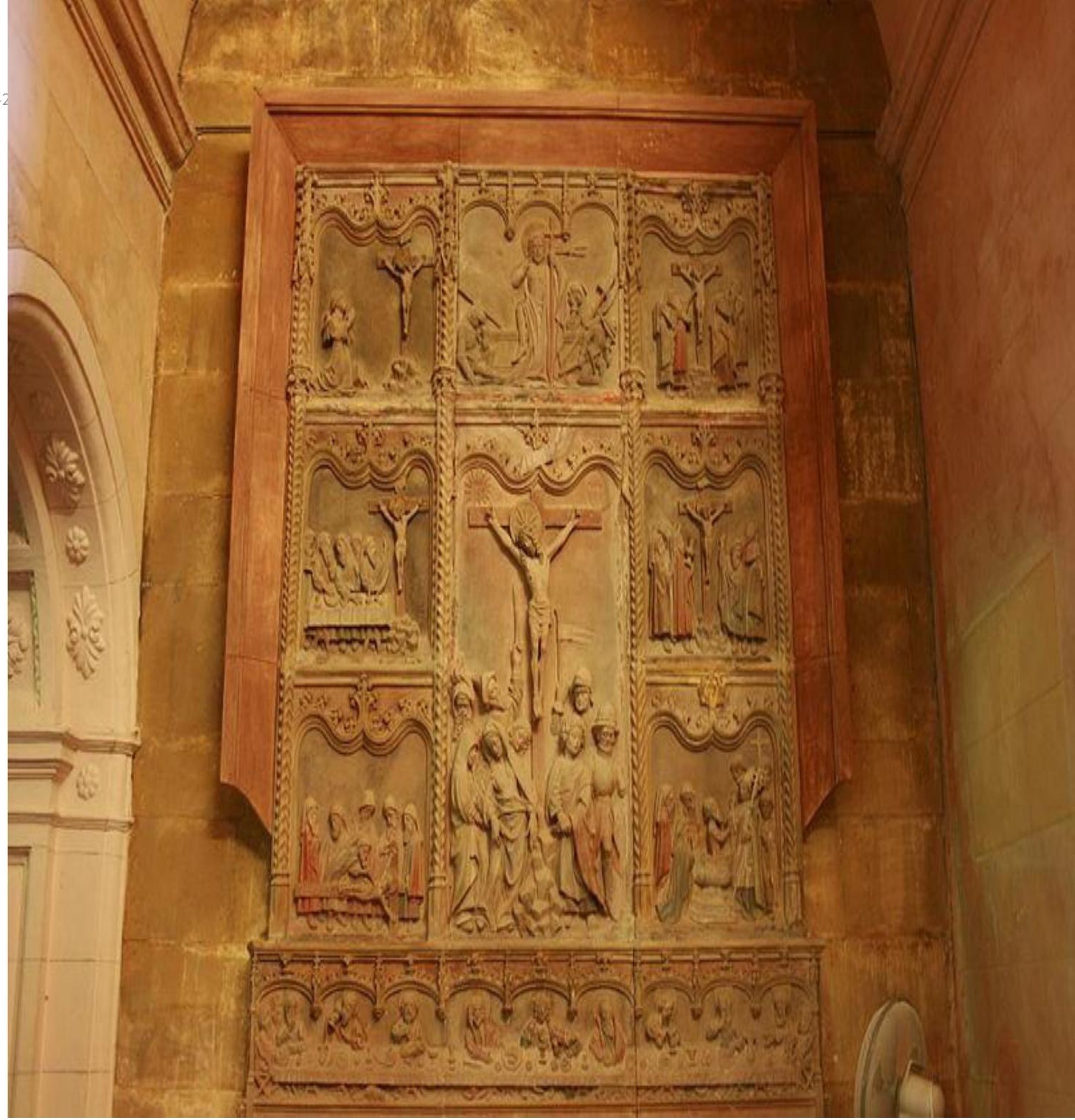

Igreja de São Salvador de Guardiola com a representação da "Pascio Imago Pietatis, so és, com los juheus bateran la image del Crucifix, e d'aquela image isqué gran multitat de sanch"52. Também sabemos que na Sé de Valência, na antiga capela da Passio Imaginis existiu um retábulo que figurava a lenda do milagre do crucifixo de Beirute, desaparecida já no século XVII. Deste restou uma gravura de que trataremos mais adiante.

Segundo o pintor tratadista espanhol Antonio Palomino (1655-1726), na Igreja de San Salvador de Valência, aquela em que o Santíssimo Crucifixo Salvador é cultuado, havia inúmeras pinturas, sendo que uma delas figurava o milagre de Beirute e outra narrava visualmente a chegada do crucifixo à Valência:

52 Rodrigo Barral. 2009, p. 127; Espí Forcín, 2014, p. 217. 
el uno, de la milagrosa venida, del santíssimo Christo de Berito, contra la corriente de aquel rio Turia; y outro, de los martyrios y lanzada, que unos bárbaros Infieles, de aquela region, executaron em dicha santa Imagen; à cuyo golpe, saliò sangre los quales estàs colocados, à los lados de el Coro, y son mano, de Juan Conchillos ${ }^{53}$.

Figura 2 Gravura de Gerónimo Vilagrasa. In: Juan Bautista Ballester, Identidad de la imagen del $\mathrm{S}$. Christo de S. Salvador de Valencia, de 1672, p. 454-455. Fonte: A obra original reproduz-

ida na imagem pertence ao acervo bibliográfico da Biblioteca

Valenciana Digital.

Atualmente, só temos certeza da existência de uma das pinturas de Conchillos: a que ficou conhecida como Rescate del Cristo de Berito. As demais, inclusive a que figura o crucifixo de Beirute sendo flagelado, ou se perdeu durante a guerra civil espanhola ou poderia estar "inacecible y maltratada en los almacenes del Museo de Valencia"54.

Das imagens a que temos acesso, encontramos a lenda da Passio Imaginis figurada no século XV no retábulo em relevo de arenito da igreja de São Miguel em Felanitx na ilha de Mallorca, hoje exposta no monastério de São Salvador (Fig. 1), onde a narrativa do milagre está retratada em seis cenas que ocupam a parte externa do retábulo ${ }^{55}$. Trata-se, portanto, da figuração dos principais momentos da lenda do milagre do Cristo de Beirute, quando o crucifixo é atacado, quando ele responde milagrosamente e o batismo dos hebreus.

$\mathrm{Na}$ obra de Juan Bautista Ballester, Identidad de la imagen del S. Christo de S. Salvador de Valencia, de 1672, foi impressa entre as páainas 454-455 a

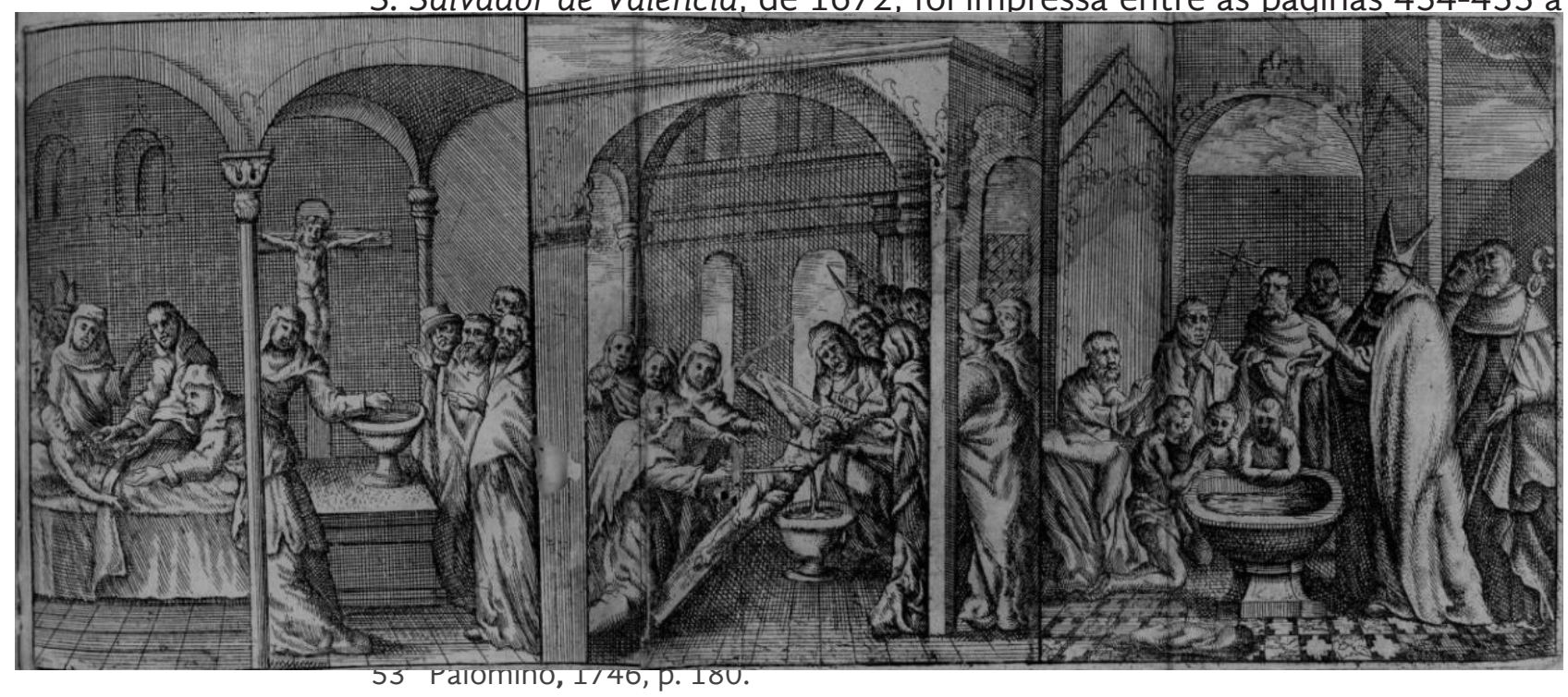

54 Pérez Sánchez, 2010, p. 395.

55 Na parte central foi figurado uma crucificação de Cristo, nela Carlos Espí Forcín identifica um dos personagens representado como Nicodemos. Espí Forcín, 2014, p. 216.

56 Pintura principal de dicha Capilla, intitulada desde poco después de la conquista [1239], de la Passione de la Imagen [...] esta de pincel antiquissimo, pintada la historia del Santo Christo de Berito, con todas su circunstancias... Balleste, 1672, p. 453-454. 
ou levado para outra localidade), nem mesmo o motivo de sua retirada. ${ }^{57} \mathrm{~A}$ gravura está dividida em três cenas, a central figura o momento do ataque e da reação milagrosa, a que está à esquerda do espectador representa o sangue sendo levado para curar enfermos e a que está à direita figura o batismo dos algozes - é interessante notar que na cena do batismo os judeus não usam mais as indumentárias típicas a eles atribuídas, como os chapéus pontiagudos.

Figura 2

Desta maneira, seja através dos calendários litúrgicos, dos textos teológicos ou das imagens narrativas, acreditamos que a divulgação da lenda da Passio imaginis poderia ter impulsionado as inúmeras denúncias feitas contra judeus e conversos de praticarem a reencenação da Paixão de Cristo por meio de crucifixos ou de simplesmente atacarem imagens cristãs na Península Ibérica do final do período medieval e início da modernidade.

\section{Iconoclastia ibérica}

Nomeamos o fenômeno em estudo neste artigo, ou seja, a violência contra as imagens, com um termo tradicionalmente utilizado para designar atos de agressão a imagens sagradas desde o século VII, em Bizâncio: iconoclastia. Cumpre ressaltar que na documentação escrita ${ }^{58}$ analisada, tais atos recebe-

57 Arciniega García, 2012, p. 81.

58 Denúncias das atas da Inquisição Portuguesa e Espanhola, textos e sermões. 
ram outras denominações. No Ocidente cristão, frequentemente os ataques às imagens religiosas foram assinalados como sacrilégio, irreverência, quebra de imagem, profanação, injuria, blasfêmia e desacato. Ao analisar os processos da Inquisição espanhola (1478), além destas designações encontramos também acusações de práticas "judaizantes"59, "luteranismos"60, ou "de mouros"61. No entanto devemos deixar claro que tais termos, qualificadores de uma determinada fé, quando aparecem nestas fontes na qualidade de um delito, poderiam significar, além de atos iconoclastas, uma infinidade de "heresias" ou "pecados" que não cabe serem discutidos aqui ${ }^{62}$.

Quando refletimos sobre a iconoclastia, para além do ato físico de destruição de imagem, devemos considerá-la como um fenômeno cultural histórico e recorrente, ou seja, um ataque contra imagens que se deu (ou que foi tido como tendo se dado) em algum momento da história, em diferentes localidades e pelos mais diversos motivos. Em princípio, qualquer tipo de imagem (e não só a religiosa, mas também a artística e a política) pode despertar tais reações violentas ${ }^{63}$. Na tradição religiosa, o fenômeno da iconoclastia também ocorreu nos mais distintos momentos da história, em diferentes localizações e confissões. O mote quase ${ }^{64}$ basilar está na ação violenta para a proteção daquilo que é considerado como a verdade de cada religião, que é importante para a manutenção de sua identidade em oposição a seus outros $^{65}$. Ou seja, o ato iconoclasta não pretende apenas fazer desaparecer

59 Eram condenados por delitos judaizantes além daqueles em condição judaica "otras actuaciones punibles según el derecho inquisitorio (blasfemias contra símbolos cristianos, proselitismo judaico, ataques a la Inquisición, tenecia y difusión de libros prohibidos, desprecio a las imágenes", etc. Sierra, 2005, p. 61-62.

60 Eram consideradas heresias luteranas, como as de que mestre Bernardo (ANTT, Inquisição de Évora, processo $n^{\circ}$ 8884) fora acusado, pois declaravam que as imagens religiosas são ídolos. Coelho, 1987, p. 235.

61 Nas causas vistas no Auto de Fé de 1603, consta a do soldado Francisco Ramirez de Valdo, foi acusado de mouro e teria dito "que los christianos creyan en unos palos y [...] que el y unos morros avian despedaçado um cruçifijo..." Sierra, 2005, pp. 505-506.

62 Sobre estas apostasias: Sierra, 2005, p. 61-110.

63 "Existiu sempre da parte dos homens - e continua a existir - uma deriva iconoclástica que se manifesta, em relação à imagem que adora, por que nutre encanto, respeito, desconforto, ou medo - de diferentes modos". Serrão, 2009, v.11. Ver também Didi-Huberman, 1994, 20, p. 159- 177.

64 Este "quase" está aqui para não limitar esta proteção às grandes disputas religiosas, pois se olharmos para casos em suas especificidades encontraremos as mais diversas razões para se destruir uma imagem. Ver: Freedberg, 1992, p. 423-474.

65 Teixeira, 2008, p. 143-174. 
a imagem ou simplesmente destruí-la, a intenção ao agredir um objeto considerado sagrado de outra religião é questionar e até mesmo extinguir as práticas a ele relacionadas ${ }^{66}$. E nas religiões nas quais as imagens religiosas exercem funções místicas ou sobrenaturais ${ }^{67}$, o ataque não fere somente a devoção, mas também agride aquele a quem a devoção é dirigida. Este é um problema teórico e religioso sobre a relação entre o original/protótipo e sua representação. Iconoclastas e iconófilos têm posições divergentes sobre a relação entre o espaço físico e o sagrado, bem como entre as pessoas e a (ou as) divindade(s), e acreditamos que seu estudo não deva ocorrer sob uma premissa generalizadora, mas sim a partir das especificidades dos casos examinados.

No mundo cristão observamos vários momentos em que o fenômeno da iconoclastia ocorreu em grande escala, como no século VIII em Bizâncio ${ }^{68}$, e no século XVI na Europa ocidental ${ }^{69}$. No Concílio de Nicéia II, os bispos iconófilos partiram de pressupostos neoplatônicos e da teoria do transitus de Damasceno, segundo a qual, de forma muito simplificada, a divindade do protótipo transmite para sua imagem uma virtude santa, a virtus sancta ${ }^{70}$, sendo este um entendimento adequado à lenda da Passio Imaginis e outras em que a imagem cristã era atacada e reagia milagrosamente manifestando sua natureza divina. No imaginário cristão, o repúdio dos judeus ao culto às imagens os teria levado a desejar destruí-las, e nesta tentativa de destruição se produzia o milagre. ${ }^{71}$ Entretanto, sabemos que para o cristianismo as questões relacionadas ao culto às imagens e objetos visuais não se resolveram no Concílio de Niceia II, elas estiveram por séculos imersas em um longo debate sobre sua pertinência nos rituais religiosos ${ }^{72}$.

66 Ver: Belting, 2005, p. 68-69.

67 Podemos citar outras religiões em que as imagens sagradas funcionam não somente como representações de divindades, como o hinduísmo. Mas as imagens exercem funções místicas também no budismo, em religiões africanas, nos cultos maori, etc. FREEDBERG, David, 1992, p. 107-126.

68 Ver: Besançon,1997, p. 179-238.

69 Freedberg, 1992, p. 423-574.

70 Wirth, 2001, pp. 29-30; García Aviles, 2010, p. 28.

71 Espí Forcín, 2008, pp. 175-176.

72 Sobre este tema ver: Schmitt, 2007, p. 55-89. 
No que se refere à Península Ibérica, o tema do culto e ataque às imagens, como já dissemos, em muitos casos esteve relacionado às fés judaicas e muçulmanas, e depois aos conversos, sendo que desde o século XIII, na Corte de Alfonso $X$, as legislações das Siete Partidas já incluíam uma lei referente a supostos rituais de simulação da Paixão de Cristo por meio sua imagem ${ }^{73}$. Deste período, na coroa de Aragão, encontamos documentada a mais antiga acusação de profanação de crucifixos da Península referente ao ano de 1266. O Contador Geral do reino e um dos favoritos de Jaime I, o judeu Jahuda de la Canallería, com sua esposa e filha, foram acusados de possuir um crucifixo e realizar rituais de encenação da Paixão. Como a investigação não encontrou provas de tal vilipêndio, o rei de Aragão os perdoou $^{74}$. Todavia, foi no século XV que as acusações de iconoclastia e injúrias às imagens ${ }^{75}$ proliferavam e que os acusados de tal agravo eram castigados com severidade pelo Santo Ofício. A prática do culto às imagens tornou-se, ao contrário, um símbolo irrepreensível da qualidade de cristão-velho ${ }^{76}$. Desta maneira, a leitura da documentação da Inquisição Espanhola revela que no final do medievo e início da modernidade a questão da devoção às imagens converteu-se em verdadeiro símbolo da discórdia social, como bem disse Felipe Pereda ${ }^{77}$.

\section{Considerações Finais}

É importante lembrar que no decorrer dos séculos XIII, XIV e XV houve, na Península lbérica $^{78}$, uma expansão da importância das imagens religiosas nas práticas devocionais cristãs; as imagens sagradas, que até então eram restritas aos altares e outros ambientes eclesiásticos, passaram a ser cada

73 Las siete partidas. Partida 7, Título 24, ley II.

74 Archivo de la Corona de Aragón. Cancillería Real, fol. 36v.

75 Processo de Fé de Juan Falcó, 1484-1485, ES.28079.AHN//INQUISICIÓN,146, Exp.2; Processo de Fé de Francisco Valero, 1489-1490, ES.28079.AHN//INQUISICIÓN,187, Exp.2; Processo de Fé de Juan de Peraile, 1486, ES.28079.AHN//INQUISICIÓN,174, Exp.14, estes são só alguns exemplos de Processos de Fé custodiados no Arquivo Histórico Nacional da Espanha, cuja acusação fora atacar crucifixos.

76 Espeso Pereda, 2002, p. 62.

77 Espeso Pereda, 2007, Posição 63-5673.

78 A principal referência principal para o tema das imagens religiosas na Espanha do período: Espeso Pereda, 2007. 
vez mais cultuadas também nos espaços domésticos. ${ }^{79}$ Deste modo, houve um aumento do número de imagens religiosas que escapavam ao controle clerical. Além disso, a busca pelo controle territorial e da efetivação da Reconquista ${ }^{80}$ fez crescer a necessidade da ampliação do cristianismo (domínio religioso), o que culminou com as conversões forçadas ${ }^{81}$ e a instituição da Inquisição ${ }^{82}$, por consequência as questões relacionadas ao culto às imagens religiosas se tornaram mais presentes.

Não se pode esquecer que a tradição cristã considera o Cristo como o Salvador, o Messias, e que os judeus teriam sido responsáveis por seu sofrimento e morte. Desta forma, as lendas e acusações de Passio Imaginis ou as encenações da Paixão por meio de crucifixos acabaram funcionando como um dos inúmeros topoi antijudaicos durante os últimos séculos da Idade Média e início da modernidade ${ }^{83}$. Ao mesmo tempo, elas poderiam manter um caráter salvífico vinculado à consagração do culto às imagens e à conversão. Para o cristianismo da época, os judeus eram considerados a matriz dos ataques iconoclastas, porque desejariam fazer com a imagem de Cristo o mesmo que teriam feito com seu protótipo na cruz. Ou seja, o ataque imagem seria um sinal da persistência do suposto caráter deicida judaico. No entanto, com o decorrer do tempo outros agentes acusados de profanadores passaram a fazer parte das narrativas: no caso da Península Ibérica, primeiramente os muçulmanos e mais tarde os conversos; e até mesmo reformistas chegaram a ser acusados de iconoclastas em terras

79 Espeso Pereda, 2007, Posição 741-5673. De maneira geral, como aponta Jérôme Baschet, na Europa Ocidental a partir do século XII as imagens passaram a ocupar um lugar para além dos monastérios e igrejas, sendo encontradas pinturas, esculturas e manuscritos iluminados nos lares cristãos, em um esforço de estabelecer um contato com Deus e os santos fora do momento da liturgia. Baschet, 2006, p. 495-500.

80 Machado, 2010, p. 104-122.

81 A expulsão ou as conversões forçadas aconteceram na Espanha em 1492 para os judeus e 1502 para os mouros, em Portugal 1497 para as duas religiões.

82 Inquisição espanhola (1478-1834) e Inquisição Portuguesa (1531-1821).

83 Além de simulação da paixão com crucifixo, os judeus também eram acusados de praticar outros crimes rituais como a profanação de hóstias e até mesmo a crucificação de crianças cristãs. Segundo Raul Gonzalez Salinero, tais acusações teriam acontecido em vários locais da Europa, e o primeiro caso que se tem notícia teria sido o assassinato ritual de um garoto na Inglaterra em 1144, relatado na legenda Vita et Miracula St. Wilelmi Norwicensi (1173) do monge beneditino Thomas de Monmuth. Gonzalez Salinero, 2013, p. 65-82. 
hispânicas (como no restante da Europa).

Por fim, sabemos que os textos que narram as lendas aqui apresentadas foram redigidos por clérigos com o objetivo de glorificar a religião cristã, e apesar de serem documentos que nos dão acesso a aspectos da realidade passada, não podemos nos enganar, são textos que seguiam regras retóricas, em que se empregava muito esforço para adequar o relato milagroso à sua finalidade ${ }^{84}$. No caso destas lendas, a finalidade é exaltar a virtude santa das imagens e a importância do seu culto na economia da salvação. Já nos processos do Tribunal do Santo Oficio, os inquisidores conduziam suas investigações no sentido de comprovar a suposta existência de uma conspiração contra a fé cristã (e depois, católica) ${ }^{85}$. Embora não possamos tomar como fato os ataques ali relatados, sabemos que atitudes iconoclastas existiram; as guerras de religião, além de mortos, deixaram muitas ruínas. As concepções religiosas judaica e moura também poderiam ser propulsoras de atitudes iconoclastas, sem esquecer do caso dos cristãos-velhos, que por inúmeros motivos podiam expressar seu ódio atacando imagens ${ }^{86}$. Em síntese, mais do que descrever atos iconoclastas como fatos, ou reportar a existência de uma "maldade" ou "desejo" intrínseco aos judeus, mouros e conversos de destruir imagens, a circulação da lenda da Passio Imaginis e as suas derivações hispânicas, no final da Idade Média e começo da Moderna, nos esclarece sobre a concepção cristã ibérica de seus inimigos religiosos, bem como sua compreensão do poder que as imagens religiosas exerciam no interior de sua fé.

\section{Referências}

AMARAL, Debora G. P. A Iconoclastia nas pinturas da Capela do Antigo Convento dos Capuchinhos da Paciência de Madri (Século XVII). Dissertação (Mestrado em História Social) - FFLCH - Departamento de História. UPS. São Paulo 2016

84 Vauchez, 2006, p. 199-202.

85 Os inquisidores filtravam todos os relatos, decidiam o que perguntar, e, em muitos casos qual seria a resposta correta. Ginzburg, 1989, p. 15-39; Pulido Serrano, 2002, p. 147-152.

86 Marchal; Riviére, 1995. p. 1135-1156. 
AQUINO, Tomás. Suma Teológica, Parte III. Questão 54. Art. 2. Versão online: http://permanencia.org.br/drupal/node/3512.

ARON-BELLER, Katherine. Fictional Tales and Their Narrative Transformations: Accusations of Image Desecration Against Jews in 12th and 13th Century Europe. In: Antisemitism Studies, Indiana: Indiana University Press v. 1, n. 1, 2017.

ARCINIEGA GARCÍA. Luis. La Passio Imaginis y la adaptativa militancia apologética de las imágenes en la Edad Media y Moderna a través del caso Valenciano. In: Ars Longa. València, n² 21, p. 71-94, 2012.

BACCI, Michele. The Berardenga Antependium and the Passio Ymaginis Office. In: Journal of the Warburg and Courtauld Institutes, v 61. London: The Warburg Institute, 1998.

BACCI, Michele. Quel bello miracolo onde si fa a la festa del santo Salvatores. Studio sulle metamorfose di una legenda. ROSSETTI, G. Santa Croce e Santo Volto: Contributi allo studio dell'origine e dela fortuna del culto del Salvatore (secoli IX-XV). Pisa: Gesem, 2002.

BACCI, Michele. Le Majestat, il Volto Santo e il Cristo di Beirut: nuevo riflessioni. In: Iconographica: studies in the history of images, XIII. Firenze: SISMEL, 2014.

BALLESTER, Juan Bautista. Identidad de la imagen del S. Christo de S. Salvador de Valencia, 1672.

BASCHET, Jérôme. A civilização feudal: do ano mil à colonização da América. São Paulo: Globo, 2006.

BESANÇON, Alain. A imagem proibida: uma história intelectual da iconoclastia. Rio de Janeiro: Bertrand Brasil, 1997.

BELTING, Hans. Puissance et impuissance de l'image. In: Revue des sciences sociales, $n^{\circ} 34,2005$.

BÍBLIA de Jerusalém. São Paulo: Paulus, 2011.

BISHKO, Charles Julian: The Spanish and Portuguese Reconquest, 10951492. In: SETTON, Kenneth M. (org.) A History of the Crusades, vol III. Cambridge: Cambridge University Press, p. 396-456, 1975. 
BLEDA, Jaime Juan. Los Cuatrocientos milagros, y muchas alabaças de la Santa Cruz, 1600.

COELHO, Antonio Borges. Inquisição de Évora: dos primórdios a 1668. Lisboa: Caminho-Colecção Universitária, 1987.

DIDI-HUBERMAN, Georges. Poderes da figura. Exegese e visualidade na Arte Cristã. In: Revista de Comunicação e Linguagens, 1994.

ESPESO PEREDA, Felipe. El debate sobre la imagen en la España del siglo $\mathrm{XV}$ : judíos, cristianos y conversos. Anuario del departamento de Historia y teoría del Arte, Madrid, vol XIV, p. 59-79, 2002.

ESPESO PEREDA, Felipe. Las imágenes de la discordia: política y poética de la imagen sagrada en la España del cuatrocientos. Madrid: Marcial Pons, 2007. Edição Kindle.

ESPÍ FORCÍN, Carlos. Heredereos de la Culpa. Antijudaísmo en la cultura visual hispánica dela Baja Edad media. Tese (Doutorado em História da Arte) Departamento del Historia del Arte - Universidade de Murcia, 2008.

ESPÍ FORCíN, Carlos. De Oriente a Occidente. La leyenda bizantina de la Passio Imaginis en el siglo XV en la corona de Aragón. In: Estudios Bizantinos, 2. Madrid: Sociedad Española de Bizantinística, 2014.

ESPINA, Alonso de. Fortaleza da Fé, Livro III. Decima consideracíon. Quinto admirable. Edição Kindle, 2014.

FERRER NAVARRO, Ramón. Conquista y Repoblacíon del Reino de Valencia. València: Promocio de Cultura Valenciana del Senia al Segura, 1999.

FREEDBERG, David. El poder de las Imágines. Madrid: Cátedra, 1992.

FROZ. H. (ed.). Bibliotheca hagiographica latina. Bruxelles, 1891-1901.

GARCIA AVILES, Alejandro. Transitus: actitudes hacia a la sacralidad de las imágenes en el Occidente medieval, In: Imágenes medievales de culto. Tallas de la colección el Conventet. Murcia: Museo Arqueológico, p. 25-35, 2011,

GARCÍA FITZ, Francisco. La Reconquista: un estado de la cuestión. In: Clio \& Crimen, $\mathrm{n}^{\circ}$ 6. Durango: Centro de Historia del Crimen, 2009, p. 142-215. 
GONZÁLEZ SALINERO, Rául. Manos manchadas de sangre: los orígenes cristianos del mito antijidío del crimen ritual. In: Collectanea Christiana Orientalia v. 10. Cordoba: Universidade de Cordoba, 2013.

GINZBURG, Carlo. Mitos, Emblemas e Sinais: Morfologia e História. São Paulo: Companhia das Letras, 1989.

GURPEGUI, Félix-Tomás López. Introdução. Alonso de Espina. Gerra contra los judios. Libro III del Fortalitium Fidei, 2014.

MACHADO, Heloisa Guaracy. "Reconquista cristã. Guerra e religiosidade no cancioneiro mariano afonsino." In: Cadernos de História. Belo Horizonte, V. 11, n. 14, p. 104-122, 2010.

MANSI, G. D. Sacrorum conciliorum nova et amplissimacollectio, vol. XIII. Firenzi/Venezia, 1759-1798.

MARCHAL, Guy P.; RIVIÉRE, Véronique. Jalons pour une histoire de l'iconoclasme au Moyen Âge. In: Annales. Histoire, Sciences Sociales, N. 5, p. 1135-1156, 1995.

PALOMINO, Antonio. Las ciudades, iglesias y conventos en España, 1746.

PEREIRA, Marcia Cristina. As letras e as imagens: iniciais ornamentadas em manuscritos do Ocidente Medieval. São Paulo: Intermeios, 2019.

PÉREZ SÁNCHEZ, Alfonso E. Pintura Barroca en Enspaña: 1600-1750. Madrid: Cátedra, 2010.

PULIDO SERRANO, Juan Ignacio. Injúrias a Cristo: religión, política y antijudaísmo en el siglo XVII. Alcalá de Henares: Instituo Internacional de Estudios Sefardíes y Andalusíes - Universidad de Alcalá, 2002.

RODRIGUEZ BARRAL, Paulino. La imagen del judío en la España medieval. El conflicto entre cristianismo y judaísmo en las artes visuales góticas. Barcelona: Memoria Artium. 2009.

RUCQUOI, Adeline. História Medieval da Península Ibérica. Lisboa: Estampa, 1995.

SÁEZ, Adrián J. Los Cuatrocientos milagros de la Cruz: ¿Libro de cabecera de Calderón? In: Atalanta: Revista de las Letras Barrocas. Sevilla,v.1, nº.1, 2013. 
SANSTERRE, Jean-Marie. L'image blessée, l'image souffraten: quelques recits de miracles entre Orient et Occident (VI-XII siècles). In: Les images dans les sociétés médiévales: pour une histoire comparée. Bruxelles: BHIR, 69, p. 113-130, 1999.

SCHMITT, Jean-Claude. O corpo das imagens. Ensaios sobre a cultura visual na Idade Média. São Paulo: Edusc, 2007.

SERRÃO, Vitor. A pintura maneirista e proto-barroca. RODRIGUES, Dalila (org.). Arte Portuguesa da pré-história ao século XX. Lisboa: Fubu, v.11, 2009.

SIERRA, Julio. Procesos de la Inquisicion en Toledo (1575-1610): Manuscrito de Halle. Madrid: Trotta, 2005.

TEIXEIRA, Alfredo. Uma política da imagem: leitura antropológica da blasfémia visual de Pierre Legendre. In: Revista Portuguesa de História, Coimbra, 2008.

VARAZZE, Jacopo de. Legenda Áurea: vida de santos, 2003.

VAUCHEZ, André. "Milagre". Milagre. In: LE GOFF, Jacques e SCHMITT, Jean-Claude (org). Dicionário temático do Ocidente Medieval. São Paulo: Edusc, v. II, 2006.

WIRTH, Jean. Faut-il adorer les images? La théorie du culte des images jusqu'au concile de Trente. DUPEAUX, Cécile; JEZLER, Peter e WIRTH, Jean. Cataloque de l'exposition: Iconoclasme: vie et mort de l'image médievale. Paris: Somogy, 2001.

\section{Lista de figuras}

Fig. 1. Retábulo, séc. XV, igreja de São Miguel em Felanitx de Mallorca.

Fig. 2. Gerónimo Vilagrasa, gravura. In: Juan Bautista Ballester, Identidad de la imagen del S. Christo de S. Salvador de Valencia, de 1672, p. 454-455. 